\title{
A structural relationship between the sufficiency economy philosophy and the transport performance of small and medium- sized enterprises (SMEs) in Thailand
}

\author{
Pisit Potjanajaruwit ${ }^{1, *}$ \\ ${ }^{1}$ Suan Sunandha Rajabhat University, 1, U-Thong Nok Road, Dusit, Bangkok, Thailand
}

\begin{abstract}
The purposes of this study were; (1) to explore the application level of the Sufficiency Economy Philosophy in Small and Medium-sized Enterprises in Thailand, and (2) to explore the relationship between the Sufficiency Economy Philosophy and business performance of Small and Medium-sized Enterprises in Thailand. The assigned sample population included 395 business owners of Small and Medium-sized Enterprises in Thailand and a questionnaire was used as a tool for data collection. The statistics used in the analysis were Arithmetic Mean, Standard deviation, and the Pearson Product Moment Correlation Coefficient with defined statistical significance of .05. The study revealed that the application level of the Sufficiency Economy Philosophy to business management of Small and Medium-sized Enterprises in Thailand was at a high level. Knowledge in the Sufficiency Economy Philosophy, however, was applied at a moderate level. It was found that the relationship between the application of the Sufficiency Economy Philosophy and the business performance of Small and Medium-sized Enterprises in Thailand was a significant relationship with statistical significance of .05 . For the related components; Moderation, Reasonableness, Social Immunity, Knowledge, and Virtue, each was also found relevant to the business performance of Small and Medium-sized Enterprises with statistical significance of .05 .
\end{abstract}

\section{Introduction}

After the economic crisis in 1997, His Majesty King Bhumibol emphasized the use of the Sufficiency Economy Philosophy that focuses on making the development of the Thai economy more sustainable. This philosophy of the Sufficiency Economy which had been brought up by His Majesty constantly throughout his reign is a philosophy that focuses on the middle path for the way of life of Thai people at all levels. The Sufficiency Economy Philosophy is consistent with business strategies that focus on keeping balanced development in response to globalization and prevention of the effects that may come from both internal and external factors [1]. With its emphasis on Moderation, Reasonableness, Social Immunity, together with Virtue and Knowledge, the Sufficiency Economy

\footnotetext{
*Corresponding author: pisit.po@ssru.ac.th
} 
Philosophy is particularly suitable for the management of 4 capitals - physical capital, human capital, natural capital, and social capital - which is an important factor for economic growth with quality and stability.

It might be necessary for both public and private sectors to apply the Sufficiency Economy Philosophy as reflected through the lessons on the economic crisis in the years 1997-1998, which showed Thailand's lack of moderation, knowledge, prudence, and virtue. It is therefore imperative for the government to formulate economic management policies under the Sufficiency Economy Philosophy to achieve well-being and quality of life of people under the current economic, social, and political changes [2].

It can be seen in the current economic conditions that Thailand is affected by risk factors and several limitations, especially from external factors such as oil price, interest rates, and exchange rates, as well as natural disasters that are difficult to predict and the political stagnation which affects government spending and investment.

These factors show signals that they will continue to have an effect on the Thai economy in the future and will also affect the economy of Small and Medium-sized Enterprises or SMEs of Thailand. While most people agree that Small and Medium-sized Enterprises, known in short as SMEs, are the key to the country's strong development, for SMEs to become successful is not an easy matter and it seems to become more and more difficult due to SMEs' nature of being small in size and the intensity of business competition that is becoming more intense today with globalization [3].

The Office of Small and Medium Enterprises Promotion or OSMEP has compiled and defined a plan in the SME Promotion Project in accordance with the 2nd SME Promotion Master Plan of 2007 - 2011, which adopted the Sufficiency Economy Philosophy in the 10th National Economic and Social Development Plan and government policy as the main idea in supporting SMEs in each important strategy.

To apply the Sufficiency Economy Philosophy in real situations, the government sector should guide entrepreneurs for them to better understand the concept of the Sufficiency Economy Philosophy. They must also set an example as a promoter and facilitator for both the private and public sectors. In addition, there should also be contribution of appropriate knowledge to assist entrepreneurs to be more knowledgeable, skilled, adaptable, and selfreliant in order to develop local products and the local communities with stability and sustainability [4].

The aforementioned issues led to this research study on the structural relationship between the Sufficiency Economy Philosophy and the business performance of Small and Medium-sized Enterprises in Thailand.

The purposes of this study were (1) to study the application level of the Sufficiency Economy Philosophy of Small and Medium-sized Enterprises in Thailand and (2) to explore the relationship between the Sufficiency Economy Philosophy and the business performance of Small and Medium-sized Enterprises in Thailand. The results obtained from this research can be used a guideline for improving and developing the entrepreneurial potential of Small and Medium-sized Enterprises and might be useful for the operations of other enterprises with similar operations.

\section{Methodology}

\subsection{Study Design}

The study was a survey that used quantitative research methodology. The data collection was conducted using the Simple Cross-Sectional Design with data gathered one time before being processed using statistical analysis. 


\subsection{Determination of Population and Sample}

The population used in the research was 28,448 business owners or people from other equivalent positions of the 28,448 Small and Medium-sized Enterprises in Thailand [5].

The sample group was selected using the Multistage Sampling as follows;

Step 1: Select the samples using Purpose Sampling based on this research's specified characteristic of the sample group, namely, holding ownership or other equivalent position of Small and Medium-sized Enterprises in Thailand.

Step 2: Find the total number of Small and Medium-sized Enterprises in Thailand which is 28,448 a number that represents all Small and Medium-sized Enterprises located in Thailand.

Step 3: The population of Small and Medium-sized Enterprises in Thailand is a constant number. Therefore, it is considered a finite population that can be sampled with statistical probability. Thus, sample subjects were selected using these following steps [6].

From the total population of 28,448 people, the sample size is needed at the error level of .05. Substitute $\mathrm{n}=394.45$ () 28128 .

Therefore $\mathrm{n}=395$ people 205.0448 ,

Step 4: Out of the total 28,448 Small and Medium-sized Enterprises in Thailand, the Simple Random Sampling was done by drawing lots to select 395 samples of Small and Medium-sized Enterprises. The selected samples could be divided into 121 Medium-sized and 274 Small-sized Enterprises, which together made up the total number of 395 for the sample group.

Table 1. Key informants or SME entrepreneurs as classified by their type and size of business.

\begin{tabular}{|l|c|c|}
\hline \multicolumn{1}{|c|}{ Type/Size of enterprises } & Medium-sized & Small-sized \\
\hline 1. Manufacturing & 53 & 88 \\
\hline 2. Retail & 26 & 100 \\
\hline 3. Wholesale & 22 & 34 \\
\hline 4. Services & 20 & 52 \\
\hline Total of each size & 121 & 274 \\
\hline Total & \multicolumn{2}{|c|}{395} \\
\hline
\end{tabular}

\subsection{Study tools}

The instrument used in this research was a structural questionnaire created by theresearcher from the study on the related documents about the Sufficiency Economy Philosophy and other relevant studies that were consistent with the research framework. The creation process of this questionnaire was as follows [7];

1. Review the relevant literature. This study used collected data from research pieces, study results, and other documents with relevant theories, concepts, and philosophy with the Sufficiency Economy Philosophy, including related research results consistent with the conceptual framework and various questionnaires that could be applied in this research.

2. Determine the scope and content of the questionnaire using the summary of information obtained from literature review in order to create an inclusive questionnaire with content that is consistent with the concept and purposes of this research study. The questionnaire was then summated to experts to evaluate its Content Validity, which the IOC of the entire questionnaire was found at 0.67-1.00.

3. Test the revised and approved questionnaire for reliability by using it with a population of 30 people with similar characteristics to the sample to be studied - both in residential and demographic characteristics. The result of the survey was obtained and 
checked for its reliability using Cronbach's Alpha Method. The test result revealed that the questionnaire had an overall alpha value of .9555 , indicating that the questionnaire had a high level of reliability.

\subsection{Data analysis and summary}

The collected data was recorded and entered in a computer by using a package program for social science research. The data was analyzed using descriptive statistics such as Percentage, Mean, and Standard Deviation. Inferential Statistics, such as the Pearson Product Moment Correlation Coefficient, were also used with a statistical significance at 0.05 .

\section{Results}

The results of descriptive statistics analysis in the application of Sufficiency Economy Philosophy to business management of Small and Medium-sized Enterprises in Thailand in the areas of Moderation. Reasonableness, Social Immunity, Knowledge, and Virtue are shown in Table 2

Table 2. Mean (X), Standard Deviation (S.D.) and the application level of the Sufficiency Economy Philosophy to business management of Small and Medium-sized Enterprises in Thailand.

\begin{tabular}{|l|c|c|c|}
\hline $\begin{array}{c}\text { Application of the Sufficiency } \\
\text { Economy Philosophy }\end{array}$ & $\overline{\mathbf{X}}$ & S.D. & $\begin{array}{c}\text { Application } \\
\text { Level }\end{array}$ \\
\hline 1. Moderation & 3.79 & 0.48 & High \\
\hline 2. Reasonableness & 3.70 & 0.44 & High \\
\hline 3. Social immunity & 3.52 & 0.43 & High \\
\hline 4. Knowledge & 3.48 & 0.53 & Moderate \\
\hline 5. Virtue & 3.88 & 0.53 & High \\
\hline Overall & 3.68 & 0.40 & High \\
\hline
\end{tabular}

As shown in Table 2, it was found that the application of the Sufficiency Economy Philosophy in business management of Small and Medium-sized Enterprises in Pathum Thani Province was found at a high level $(\overline{\mathrm{X}}=3.68)$. When considered based on each component, it was found that 4 components of the philosophy were applied at a high level and 1 component was found at a moderate level. They are listed based on their Mean score from the highest to the lowest as follows; Virtue $(\overline{\mathrm{X}}=3.88)$, Moderation $(\overline{\mathrm{X}}=3.79)$, Reasonableness $(\overline{\mathrm{X}}=3.70)$, Social Immunity $(\overline{\mathrm{X}}=3.52)$, and Knowledge $(\overline{\mathrm{X}}=3.48)$.

Table 3. Mean $) \bar{X}($, Standard Deviation (S.D.) and Business Performance Levels of Small and Medium-sized Enterprises in Thailand.

\begin{tabular}{|l|c|c|c|}
\hline $\begin{array}{c}\text { Business Performance of Small and } \\
\text { Medium-sized Enterprises }\end{array}$ & $\overline{\mathbf{X}}$ & S.D. & Level \\
\hline 1. Human capital & 3.46 & 0.49 & Moderate \\
\hline 2. Social capital & 3.44 & 0.49 & Moderate \\
\hline 3. Natural capital & 3.61 & 0.52 & High \\
\hline 4. Physical capital & 3.58 & 0.53 & High \\
\hline Overall & 3.52 & 0.43 & High \\
\hline
\end{tabular}


From Table 3, the business performance of Small and Medium-sized Enterprises in Thailand was found at a high level $(\overline{\mathrm{X}}=3.52)$. When considered based on the capital type, 2 capital types were found at a high level and the other 2 were found at a moderate level. They are listed based on their Mean score from the highest to the lowest as follows; environmental capital $(\overline{\mathrm{X}}=3.61)$, physical capital $(\overline{\mathrm{X}}=3.58)$, human capital $(\overline{\mathrm{X}}=3.46)$, and social capital $(\overline{\mathrm{X}}=3.44)$.

Table 4. Correlation Coefficient between the Application of Sufficiency Economy Philosophy and the overall business management of Small and Medium-sized Enterprises

\begin{tabular}{|c|c|}
\hline Variable & Correlation Coefficient \\
\hline Application of the Sufficiency Economy Philosophy & $0.829^{*}$ \\
\hline Moderation & $0.611^{*}$ \\
\hline Reasonableness & $0.709^{*}$ \\
\hline Social Immunity & $0.600^{*}$ \\
\hline Knowledge & $0.739^{*}$ \\
\hline Virtue & $0.720^{*}$ \\
\hline
\end{tabular}

* Statistically significant at 0.05

From Table 4, it was found that the application of the Sufficiency Economy Philosophy in business management was significantly related to the business performance of Small and Medium-sized Enterprises at the .05 level $(r=0.829)$. Additionally, the application of each component of the Sufficiency Economy Philosophy - Moderation $(r=0.611)$, Reasonableness $(r=0.709)$, Social Immunity $(r=0.600)$, Knowledge $(r=0.739)$, and Virtue $(r=0.720)$ - was also found to be related to the business performance of Small and Medium-sized Enterprises with a statistical significance of .05 .

\section{Conclusion}

According to the analysis results, the component of the Sufficiency Economy Philosophy that was found most applied among the Small and medium-sized Enterprises in Thailand was Virtue $(\overline{\mathrm{X}}=3.88)$, as it was applied at a high level. This means that if the SMEs have virtue (conduct business or compete with others fairly, take no advantage of any stakeholder of the business and society, provide welfare in addition to the governmentrequired level to their employees, create good working conditions, and listen to opinions as well as appropriately involve their employees in conducting business) at a high level, it will also affect the application level of the Sufficiency Economy Philosophy. This is in line with the research of [6], which explored the application of the royal Sufficiency Economy Philosophy in small and medium-sized medium industries.

The study gathered examples of His Majesty King Bhumibol's royal words as given on several occasions and concluded that the applications of the Sufficiency Economy Philosophy in industries are - to do business without being too greedy, focus not on shortterm profits, operate with honesty in the operations, take no advantage of consumers, and never oppress the laborers, customers, or even suppliers. By doing so, it will enable the business to grow sustainably long term.

Furthermore, SMEs that applied the Sufficiency Economy Philosophy to their general business management were found with the highest correlation coefficient in the application of the Sufficiency Economy Philosophy's Knowledge $\left(0.739^{*}\right)$ which was at a high level. This means that if SMEs use knowledge (promote creation of new innovation among employees, reduce steps in work procedures and organizational management, continuously improve personnel's knowledge, capability, skills, and competency to be able to perform 
various tasks, allow employees to demonstrate or take part in preventing or solving problems such as in using high technology or new knowledge to produce goods or products to market, possess ability to constantly create new activities or procedures that make their business different from the competitors) at a high level, it will also affect the performance of the SMEs, resulting in their high performance as well. This is consistent with a research study by [7].

Which compared the use of the Sufficiency Economy Philosophy and capitalist economic approaches in small and medium-sized businesses. It was found that self-taught businesses - businesses that did their own research on business-related information and production procedures, and went through trial and error until they gained experience and used it to develop new products and innovations with high quality - were found to share or pass on their gained experience to interested students, clients, and the general public, allowing them to use the knowledge in their work or to further use it as a good example in their own business development. On the contrary, the entrepreneurs of capitalist businesses were found gaining their knowledge from studying abroad and brought the foreign technology back with them to use in their business operations.

These businesses, which used Modern Trade business development approach in order to keep their business up-to-date, were found to share none of their knowledge or experience with the general public.

This might be due to their focus on doing business that seeks profit more than helping society. This is consistent with a case study by $[8,9,10]$ which explored the application of the Sufficiency Economy Philosophy at Mab Aung Natural Agriculture Center, Chonburi Province. The center was found applying knowledge on environmental-friendly production management, self-reliance, production cost reduction, and expense reduction to create social immunity for the organization [11]. Therefore, businesses should organize training activities for employees in the organization which also include content and practical activities that participants can apply to their real life, for instance, household income and expense accounting, management of production, processing, and marketing, career development other than agriculture, etc.

\section{References}

1. K. Thummathai et al., Archives of Psychiatric Nursing 34(1) (2020)

2. S. Arundee et al., Procedia-Social and Behavioral Sciences 197 (2015)

3. K. Kansuntisukmongkol, Kasetsart Journal of Social Sciences 38(1) (2017)

4. W. Suvachittanont et al., Procedia-Social and Behavioral Sciences 91 (2013)

5. D. Ushakov et al., The EUrASEANs: Journal on Global Socio-Economic Dynamics 1(1) (2016)

6. L. Silanoi, Procedia-Social and Behavioral Sciences 69 (2012)

7. D. Ushakov, Actual Problems of Economics 180(6) (2016)

8. D. Ushakov, Actual Problems of Economics 175(1) (2016)

9. M. Suttipun et al., Entrepreneurial Business and Economics Review 8(2) (2020)

10. R. Vehachart et al., International Journal of Scientific and Technology Research 9(3) (2020)

11. A Př́ivara at al., Migration Letters 16(4) (2019) 